\title{
Olfactory cues and Vespula wasp recognition by honey bee guards
}

\author{
Matthew J. WoOD*, Francis L.W. RATNIEKS \\ Laboratory of Apiculture and Social Insects, Evolution and Behaviour Group, Department of Animal and Plant \\ Sciences, The University of Sheffield, Sheffield S10 2TN, UK
}

(Received 12 June 2003; revised 12 December 2003; accepted 29 December 2003)

\begin{abstract}
Guard honey bees patrol the entrance to the nest and are thought to recognise nestmates by cuticular hydrocarbons. We aimed to determine whether honey bee guards can recognise predatory common wasps Vespula vulgaris and nestmates by olfactory cues. Odours were transferred between both honey bees and wasps and the responses of guards to controlled introductions monitored. When controlling for the species of introduced insect, the transferred odour was a predictor of aggressive attacks on both bees and wasps. Carriers of incongruous, allospecific odours were antennated by more guards than carriers of conspecific odours. Olfactory cues were, therefore, transferred and guards responded not only to odour per se but also odour incongruity. Olfactory cues may therefore be important in predator recognition by honey bee guards.
\end{abstract}

Apis mellifera / guard behaviour / olfactory cue / predator recognition / common wasp Vespula vulgaris

\section{INTRODUCTION}

Guard honey bees Apis mellifera (L.) patrol the nest entrance and prevent entry by intruders (Butler and Free, 1952; Free, 1954). Conspecific intruders - bees from other colonies - steal honey and this robbing can result in the total loss of honey stores and the death of the plundered colony (Winston, 1987). Many other species also attack honey bee colonies. Hornets Vespa spp. are large enough to kill adult honeybees and may enter the colony to carry off developing larvae and pupae (Futuyama, 1986; de Jong, 1990). Similarly, yellow-jacket wasps Vespula spp. frequently kill adult honey bees at the entrance and also steal honey from the colony, a particular problem in late summer and early autumn when the annual wasp colony reaches its peak population (Spradbery, 1973; de Jong, 1990). In Sheffield, common wasps Vespula vulgaris (L.) can become abundant and have been seen to enter hives to steal both brood and honey (N.S. Badcock, pers. comm.).

Allospecific intruders could be recognised by a variety of potential cues. Honey bees have well developed vision (Giurfa et al., 1995; Lunau and Maier, 1995) and can discriminate between complex textures and patterns (Maddess et al., 1999). Honey bees also have excellent olfaction (von Frisch 1967), which is important in nestmate discrimination based on genotype-specific cues (Getz and Smith, 1983; but see Downs and Ratnieks, 1999), comb wax hydrocarbons (Breed et al., 1988a; Breed et al., 1995) and floral oil odours (Bowden et al., 1998; but see Downs et al., 2000; Downs et al., 2001).

Common wasps and honey bees are sympatric in Europe (Spradbery, 1973; Winston, 1987). There exists, therefore, the potential for coevolution between predator and prey (Futuyama, 1986). In Japan, for example, the

\footnotetext{
* Corresponding author: matt.wood@zoology.oxford.ac.uk

Present address: Edward Grey Institute, Department of Zoology, University of Oxford, Oxford OX1 3PS, UK.
} 
Asian honey bee Apis cerana japonica (Radoszkowsky) recognises the aggregation pheromone of a sympatric predator, the giant hornet Vespa mandarinia (Smith), forming a ball around the intruder until the temperature becomes high enough to kill the hornet, but not the bees. By contrast, European honeybees $A$. mellifera introduced to Japan do not respond (Matsuura and Sakagami, 1973; Ono et al., 1995).

In view of the sympatry of honey bees and common wasps and the potential ubiquity of cuticular hydrocarbons in insect recognition, the aim of this study was to examine the importance of olfactory cues in the recognition of Vespula vulgaris (L.) by honey bee guards, a sympatric wasp predator. We transferred odours between honey bees and wasps and observed their treatment by honey bee guards at the colony entrance. While guards always behaved more aggressively to wasps than bees, they were more aggressive to bees with wasp versus nestmate bee odour, and less aggressive to wasps with nestmate bee versus wasp odour. Incongruous, allospecific odours (i.e. bee with wasp odour or wasp with bee odour) resulted in increased guard antennation.

\section{METHODS}

\subsection{Study species}

Three discriminator honey bee A. m. mellifera colonies were studied at the apiary of the Laboratory of Apiculture and Social Insects. Colonies were situated $2 \mathrm{~m}$ apart to minimise drifting between colonies, were queenright with approximately 20000 workers and brood and were housed in standard two-deep Langstroth hive bodies. Each colony had a $3.5 \mathrm{~cm}$ diameter entrance hole in the lower box immediately above a $15 \mathrm{~cm}$ by $20 \mathrm{~cm}$ wooden platform to facilitate both introductions and observations. Introduced bees or wasps were placed on the centre of this platform to be contacted by guards patrolling the platform and entrance.

Nests of the common wasp $V$. vulgaris were collected during pest control visits to houses in Sheffield, and relocated to the laboratory where they were housed in $30 \times 30 \times 30 \mathrm{~cm}$ polystyrene boxes with one $5 \mathrm{~cm}$ diameter entrance hole.

\subsection{Odour transfer}

The following procedure was used to transfer odour within and among groups of honey bees and wasps. Returning honey bee foragers from each of the three discriminator colonies, and foraging wasps returning to laboratory study nests were collected. Captured insects were separated into odour recipients and odour donors. Recipients were chilled in a refrigerator at $5{ }^{\circ} \mathrm{C}$ for $20 \mathrm{~min}$ to anaesthetise them and prevent fighting. Donors were killed by placing them in a freezer at $-19^{\circ} \mathrm{C}$ for $20 \mathrm{~min}$ and then kept at $5{ }^{\circ} \mathrm{C}$ until used for odour transfers within one hour. For each odour treatment group, three recipients were place in a sealed, sterile $20 \mathrm{~mL}$ plastic Universal tube containing four donors and lightly shaken for five minutes. The recipients were then separated, placed in individual $2 \mathrm{~mL}$ Eppendorf tubes, and labelled such that introductions were blind with respect to odour treatment. Recipients were kept in an ice-box to await introduction to a discriminator colony within $30 \mathrm{~min}$.

All honey bees were introduced to their own colonies and, where appropriate, received nestmate honey bee odour. This avoided the complicating factor of non-nestmate honey bee olfactory cues. Similarly, introductions to a discriminator colony involving wasps or wasp odour transfer were conducted using wasps from the same nest. The four treatment groups were arranged thus, shown as 'recipient insect (odour transferred)' : bee (bee), bee (wasp), wasp (bee), wasp (wasp).

\subsection{Guarding assay}

The behaviour of guard honey bees was observed using a standard bioassay adapted from Breed (1983) (see Downs and Ratnieks, 1999, 2000; Downs et al., 2000, 2001) in which the cooled introduced bees and wasps were allowed to warm up enough to walk but not to fly away. Using forceps, the introduced insect was placed on the centre of the entrance platform, taking care not to disturb the guard bees. To minimise the observer's disturbance of the colony, each introduction was filmed (Sony Hi8 digital camcorder)

From video footage, each introduced insect was classified as rejected (when it was either bitten, held, carried away or stung by guards) or accepted (when no such aggressive approach was made for two minutes following introduction). In addition, we also noted evictions - when the introduced insect was physically removed from the colony entrance by guards and thrown from the platform. Eviction, therefore, is a more violent and aggressive sub-category of rejection. At least five minutes was allowed between introductions, for the number of guards to return to normal. We also determined from the video the number of approaches by guards to each introduced insect. These were classified as either aggressive or non-aggressive (guard merely antennated the introduced insect before moving away). Guard 


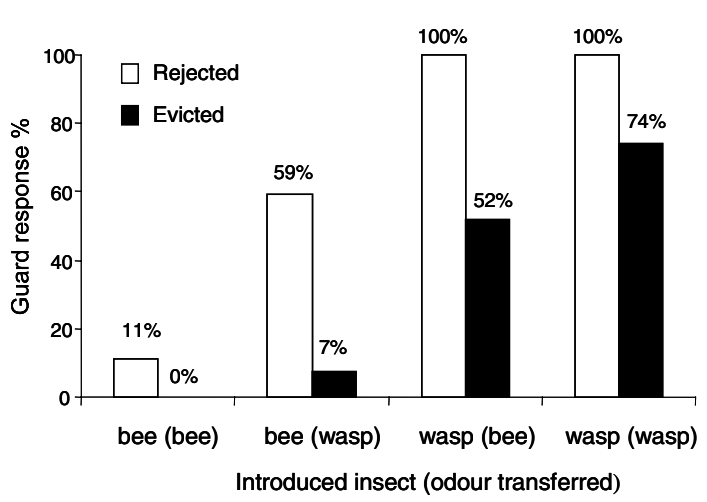

Figure 1. The percentage of introduced insects in each category rejected or evicted by honey bee guards is presented. Each category, $n=27$. approach behaviour was not considered if the insect was evicted or entered the colony in less than $10 \mathrm{~s}$, due to the difficulties in observing guard behaviour in such a short time Thereafter, the behavioural observations over a maximum of two minutes were corrected to the mean number of approaches made per $10 \mathrm{~s}$.

Twelve insects were introduced into each discriminator colony on each trial day of the experiment - three insects from each of the four treatment groups: bee (bee), bee (wasp), wasp (bee), wasp (wasp). These twelve insects were introduced in a random order to each discriminator colony. Introductions took place on three separate days in September 2001, giving a total of 108 introductions.

\subsection{Statistical analysis}

The response variables considered were the rejection/acceptance and eviction/non-eviction of the introduced insect, and the numbers of aggressive and non-aggressive guard approaches. Guard approach data were normally distributed following $\sqrt{(\mathrm{x}+1 / 2)}$ transformation prior to analysis (Finney, 1973) (Kolmogorov-Smirnov test, $P>0.05$ ).

Two predictor factors described the transferred odour: origin of the odour (bee or wasp) and its comparison with the recipient (conspecific or allospecific). This allows a distinction to be made between the odour per se, and an introduced insect with an incongruous odour (i.e. bee with wasp odour and vice versa). The sequence of introduction was included as a covariate (0-12) to control for the potential effect of an increased guard response as the introductions continue, for example in response to alarm pheromone (Morse, 1966; Morse et al., 1967). The potential random effects of discriminator colony (1-3) and the trial day (1-3) were included as categorical variables.

The response variables, rejection $(0 / 1)$ and eviction $(0 / 1)$ were analysed using a binomial logistic regression, with a logit link and the backward step- wise elimination of non-significant variables. Guard approach behaviour was analysed using a backward stepwise general linear model. In the starting model, all predictor variables and their two-way interactions were entered. At each step in model optimisation one variable was eliminated, being the variable making the least significant change in the variance explained by the model (if $P>0.05$ ), until arriving at the final model (all predictors $P<0.05$ ) (Crawley, 1993). All statistical tests were two-tailed and means are displayed \pm 1 s.e. Analyses were conducted using S.P.S.S. version 11.0.1.

\section{RESULTS}

\subsection{Guard rejection and eviction}

All wasps were rejected by guards (Fig. 1) as opposed to $35.2 \%$ of bees, so the statistical analysis of guard rejection was restricted to bees. The transfer of wasp odour was a highly significant predictor of rejection (Tab. Ia); $59.3 \%$ of bees with wasp odour were rejected by guards compared to just $11.1 \%$ of bees with bee odour. In this analysis, which is restricted to bee rejection, the origin of the odour (bee or wasp) and the incongruity of the odour (conspecific or allospecific) are equivalent. No other predictors or interactions were retained in the final model (Tab. Ia).

In the case of the eviction of introduced insects, involving sustained aggressive attacks by guards, the species of the introduced insect could be entered as a predictor, and was retained in the model ( $\mathrm{Tab}$. Ib). Furthermore, the species of the transferred odour (bee/wasp) was retained, as eviction rate was greater in bee (wasp) relative to bee (bee) and smaller in wasp (bee) relative to wasp (wasp), (Fig. 1). Eviction 
Table I. Results of a binary logistic regression, showing variables retained in the final model as significant predictors of rejection or eviction, following the stepwise backward elimination of non-significant variables. The change in model deviance $(G)$ and associated $P$-value caused by the removal of each variable retained in the final model are shown; $G$ and $P$-values are also shown for the step prior to the exclusion of variables not included in the final model. The analysis of rejection rate (Tab. Ia) is restricted to introduced nestmate bees, as $100 \%$ of wasps were rejected. In this case, transferred odour classifications 'species' and 'conspecific/allospecific' are equivalent.

a. Rejection of introduced nestmate honey bees by guards

\begin{tabular}{lccc}
\hline Variable & $\boldsymbol{G}$ & $\mathbf{d f}$ & $\boldsymbol{P}$ \\
\hline RETAINED: & & & \\
Transferred odour: bee/wasp (conspecific/allospecific) & 15.7 & 1 & $<0.001$ \\
EXCLUDED: & & & \\
Introduction sequence & 1.50 & 1 & 0.22 \\
Trial day & 1.61 & 2 & 0.45 \\
Discriminator colony & 1.67 & 2 & 0.44 \\
\hline
\end{tabular}

FINAL MODEL: $G_{l}=55.3, P<0.001$

b. Eviction of introduced nestmate bees and common wasps by honey bee guards

\begin{tabular}{lccc}
\hline Variable & $\boldsymbol{G}$ & df & $\boldsymbol{P}$ \\
\hline RETAINED: & & & \\
Introduced insect: species & 65.3 & 1 & $<0.001$ \\
Transferred odour: species & 4.97 & 1 & 0.026 \\
Trial day & 5.70 & 2 & 0.017 \\
EXCLUDED: & & & \\
Introduction sequence & 3.25 & 1 & 0.072 \\
Transferred odour: conspecific/allospecific & 1.40 & 1 & 0.24 \\
Discriminator colony & 2.05 & 2 & 0.36 \\
\hline
\end{tabular}

FINAL MODEL: $G_{4}=78.2, P<0.001$

rate also varied between trial days and no further predictors or interactions were retained in the final model (Tab. Ib).

\subsection{Guard approaches: aggression and antennation}

The number of aggressive approaches by guards to introduced insects was significantly affected by the species of introduced insect and trial day (Tab. IIa). In addition, the species of transferred odour was also retained in the final model. As in the case of eviction, aggression towards introductions was lower with trans- ferred bee odour rather than wasp odour, whether the introduced insect was a bee or a wasp (Fig. 2).

By contrast, the odour classification 'conspecific/allospecific' was retained as a significant predictor of non-aggressive guard approaches to introductions - those that involved antennation (Tab. IIb). As Figure 2 shows, bees or wasps receiving an allospecific odour treatment were antennated more by guards than bees or wasps receiving a conspecific odour. The recipient insect was a significant predictor of guard antennation, and guard antennation also varied between trial days and discriminator colony (Tab. IIb). 


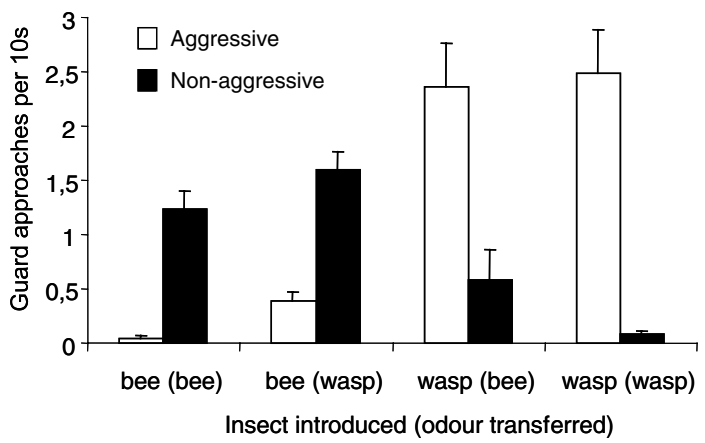

Figure 2. Approaches over the observation period were classified as either aggressive or non-aggressive and standardized as the number of approaches per 10 seconds. Each category, $\mathrm{n}=27$. Means displayed \pm 1 s.e.

Table II. Results of a general linear model, showing the variables retained in the final model as significant predictors of the number of approaches by guards that were aggressive and non-aggressive (antennation), following the stepwise backward elimination of non-significant variables. $F$-ratios and associated $P$-values are shown for the variables retained in the final model, and also for the contribution of each excluded nonsignificant variable in the step prior to its elimination. Count data were $\sqrt{(x+1 / 2)}$ transformed prior to analysis.

a. Aggression by honey bee guards toward introduced nestmate bees and common wasps

\begin{tabular}{lccc}
\hline Variable & $\boldsymbol{F}$ & df & $\boldsymbol{P}$ \\
\hline RETAINED: & & & \\
Introduced insect: species & 132 & 1 & $<0.001$ \\
Trial day & 6.02 & 2 & 0.0040 \\
Transferred odour: species & 4.67 & 1 & 0.033 \\
EXCLUDED: & & & \\
Discriminator colony & 1.85 & 2 & 0.16 \\
Introduction order & 0.58 & 1 & 0.45 \\
Transferred odour: conspecific/allospecific & 0.29 & 1 & 0.59 \\
\hline
\end{tabular}

FINAL MODEL: $F_{4,89}=201.3, P=0.001$

b. Antennation of introduced nestmate bees and common wasps by honey bee guards

\begin{tabular}{lccc}
\hline Variable & $\boldsymbol{F}$ & df & $\boldsymbol{P}$ \\
\hline RETAINED: & & & \\
Introduced insect: species & 82.4 & 1 & $<0.001$ \\
Transferred odour: conspecific/allospecific & 6.70 & 1 & 0.011 \\
Trial day & 4.31 & 2 & 0.016 \\
Discriminator colony & 3.25 & 2 & 0.043 \\
EXCLUDED: & & & \\
Introduction order & 0.91 & 1 & 0.35 \\
Transferred odour: species & 0.083 & 1 & 0.78 \\
\hline
\end{tabular}

FINAL MODEL: $F_{6,91}=224.4, P=0.001$ 


\section{DISCUSSION}

Our guarding bioassay clearly showed that odours were transferred between bees and wasps, as demonstrated by their marked effects on guard behaviour. The species of the transferred odour (i.e. bee or wasp) had a significant effect on eviction and aggression by guards. Transferred wasp odour increased eviction rate and aggressive approaches, relative to the transfer of bee odour, whether or not the introduced insect was a bee or a wasp. The species of introduced insect, bee or wasp, was always a highly significant predictor of eviction by guards, and both aggressive and non-aggressive approaches by guards. This experiment clearly shows that honey bee guards can recognise an introduced insect using transferred olfactory cues, independent of the insect carrying the odour, and modify their behaviour accordingly. Olfactory cues may therefore be of considerable importance in predator recognition by honey bee guards.

The incongruity of the transferred odour (i.e. conspecific or allospecific) remained as a significant predictor of non-aggressive approaches by guards: the presence of an incongruous odour on the recipient insect increased guard antennation. Downs et al. (2000) found that nestmate bees introduced to their natal colony carrying incongruous floral oil odours were examined for longer by guards than honey bees carrying only the colony floral odour; an increased guard decision effort with no effect on the eventual decision.

The olfactory cues involved in honey bee nestmate recognition by guards may be derived from several sources. No evidence for the use of floral oils has been found in field conditions (Bowden et al., 1998; Downs et al., 2000; Downs et al., 2001) and queen-derived chemicals (Moritz and Crewe, 1988; Breed and Stiller, 1992) are not present in detectable amounts on workers or the honeycomb (Breed et al., 1998). Endogenous heritable cues have been shown to be important in within-colony recognition, such as the aggression between sisters and half-sisters (Getz and Smith, 1983). Comb-derived hydrocarbons are rapidly acquired by workers (Breed et al., 1988a) and appear to override endogenous heritable cues in nestmate recognition (Breed et al., 1988b). Honey bee cuticles are also rich in hydrocarbons (Francis et al., 1989), which accounts for the rapid cue transfer from comb to honey bee, so cuticular hydrocarbons are a likely candidate for the olfactory cues transferred from honey bee to wasp in this experiment. The paper nests of some social wasps have been found to contain hydrocarbons, which are crucial for nestmate recognition (Singer and Espelie, 1992; Butts and Espelie, 1995; Singer and Espelie, 1996). Remarkably, Polistes social parasites avoid detection by host workers by mimicking the host's colony-specific cuticular hydrocarbon profile (Bagneres et al., 1996; Sledge et al., 2001). With the widespread occurrence of cuticular hydrocarbons in insects and their involvement in nestmate and kin recognition by Hymenoptera (Singer, 1998), common wasp olfactory cues are surely available for recognition by honey bee guards, and may have been transferred from wasp to honey bee in our experiment.

Should olfaction be revealed to be an important factor in predator recognition by guards, a number of questions arise. Has coevolution between predator and prey resulted in European honey bees being particularly sensitive to the odours of common wasps, as Japanese honey bees are to giant hornets (Ono et al., 1995), or is the degree of unfamiliarity of the olfactory cue the crucial factor? The introduction of an unfamiliar wasp to guards, such as sand wasps Bembix spp., may be informative in the latter context. The reaction of guards to such a novel cue may reveal whether responses to olfactory cues are learned or innate. As honey bees can rapidly learn rewarding flower colorations and odours (Menzel et al., 1973) and also have innate flower preferences (Giurfa et al., 1995; Lunau and Maier, 1995), both mechanisms are plausible.

\section{ACKNOWLEDGEMENTS}

This study was funded by the European Community network BABE "Beekeeping and Apis Biodiversity in Europe". David Hewett assisted with data collection. We thank Adam Hart and Stephen Martin for their valuable comments on an earlier draft of the manuscript.

Résumé - Signaux olfactifs et reconnaissance de la Guêpe commune (Vespula vulgaris) par les gardiennes de l'Abeille domestique (Apis mellifera). Les abeilles domestiques (Apis mellifera $\mathrm{L}$.) vivent 
en grandes colonies qui renferment les réserves communes de nourriture et leur couvain. Aussi ces ressources cruciales sont-elles protégées par les gardiennes à l'entrée de la colonie. Les gardiennes sont capables de discriminer les abeilles membres de la colonies des non membres, mais on sait peu de choses sur les mécanismes qui sont à la base de la défense contre les prédateurs. Dans cette étude nous avons examiné le rôle des gardiennes dans la défense de la colonie contre un prédateur de miel et de couvain communément observé : la Guêpe commune, Vespula vulgaris (L.). En fin d'été nous avons transféré des signaux olfactifs spécifiques à la colonie entre des abeilles de la colonie et des guêpes et vice versa (abeille portant l'odeur d'abeille, abeille portant l'odeur de guêpe, guêpe portant l'odeur d'abeille et guêpe portant l'odeur de guêpe). En observant la réaction des gardiennes lorsque ces insectes étaient introduits à l'entrée de la colonie, nous avons cherché à déterminer si les signaux olfactifs du prédateur influencent le comportement des gardiennes. Les signaux olfactifs ont été transférés en prenant des insectes rendus inactifs par le froid et en les secouant ensemble doucement dans des tubes de verre. Les insectes ont été ensuite séparés puis conservés au froid avant d'être réanimés et introduits à l'entrée de la colonie. Le comportement de gardiennage a été enregistré en vidéo et l'on a recherché le comportement agressif d'attaque, l'éviction de la ruche et les contacts antennaires. L'insecte portant l'odeur était important pour prédire le comportement de gardiennage. Les abeilles de la colonie ont été moins refoulées que les guêpes, moins attaquées et ont reçu plus de contacts antennaires. Les abeilles et les guêpes portant l'odeur de guêpe ont été plus souvent refoulées et traitées de façon plus agressive que celles qui portaient l'odeur d'abeille. En outre, des insectes introduits qui portaient une odeur incongrue, allospécifique (un signal contradictoire) ont reçu plus de contacts antennaires que ceux qui portaient l'odeur conspécifique. L'ampleur de certaines de ces réponses comportementales ont varié d'une colonie à l'autre et d'un jour à l'autre. Nous montrons clairement que les signaux olfactifs ont été transférés entre abeilles et guêpes avec une conséquence nette sur le comportement de gardiennage et nous discutons l'importance potentielle des signaux olfactifs dans la reconnaissance des prédateurs.

\section{Apis mellifera / Vespula vulgaris / comportement de gardiennage / gardienne / signal olfactif / reconnaissance des prédateurs}

Zusammenfassung - Geruchsreiz und Erken-
nung der Wespe Vespula durch Wächterbienen.
Honigbienen (Apis mellifera L.) leben in großen
Völkern, die die gemeinsamen Futterreserven und
ihre Brut enthalten. Diese entscheidenden Ressour-
cen werden durch Wächterbienen am Nesteingang
bewacht. Es ist gut untersucht, dass Wächter zwi- schen Volksmitgliedern und nicht dazu gehörenden Bienen unterscheiden können. Aber nur wenig ist über die Mechanismen bekannt, die der Verteidigung gegen Feinde zugrunde liegen. In dieser Studie untersuchen wir die Rolle der Wächter bei der Verteidigung des Volkes gegen einen häufigen Räuber von Brut und Honig: die Wespe Vespula vulgaris (L.). Im Spätsommer übertrugen wir volksspezifische Duftstoffe von Volksmitgliedern auf Wespen und vice versa (Bienen mit ihrem Volksgeruch, Bienen mit Wespenduftstoffen, Wespen mit Volksgeruch und Wespen mit Wespenduftstoffen). Unser Ziel war, durch Beobachtung der Reaktion der Wächterbienen nach Einbringung dieser Insekten in das Flugloch zu bestimmen, ob der Geruch von Räubern das Verhalten der Wächterbienen beeinflusst. Die Duftreize wurden durch sanftes Durchmischen von gekühlten inaktiven Insekten in einem Glasbehälter übertragen. Nach ihrer Aufteilung wurden die Insekten gekühlt aufbewahrt und erst zur Einführung in das Flugloch wiederbelebt. Das Verteidigungsverhalten wurde mit einem Videogerät aufgenommen und auf aggressive Angriffe, Vertreibung und Befühlen mit Antennen ausgewertet. Zur Vorhersage des Wächterverhaltens war das Insekt wichtig, das mit den Duftstoffen versehen war: Volksmitglieder wurden seltener vertrieben als Wespen, weniger angegriffen und häufiger mit Antennen betastet (Tab. I). Honigbienen oder Wespen, die Wespenduftstoffe trugen, wurden häufiger vertrieben und starker angegriffen als solche mit Bienenduftstoffen. Außerdem wurden eingesetzte Insekten, die mit einem unpassenden, allospezifischen Duft (widersinniger Reiz) versehen waren, häufiger mit Antennen betastet als die mit dem conspezifischen Duft. Die Stärke einiger Verhaltensreaktionen variierte zwischen den Völkern und Versuchstagen (Tab. II). Wir können deutlich zeigen, dass Duftreize zwischen Honigbienen und Vespula übertragen werden und auffällige Konsequenzen im Verteidigungsverhalten erzeugen. Wir diskutieren eine mögliche Bedeutung von Duftreizen in der Feinderkennung.

Apis mellifera / Verteidigungsverhalten / Geruchsreize / Feinderkennung / gemeine Wespe / Vespula vulgaris

\section{REFERENCES}

Bagnères A.G., Lorenzi M.C., Dusticier G., Turillazzi S., Clément J.L. (1996) Chemical usurpation of a nest by paper wasp parasites, Science 272,889 892.

Bowden R.M., Willamson S., Breed M.D. (1998) Floral oils: their effect on nestmate recognition in the honeybee, Apis mellifera, Insectes Soc. 45, 209 214.

Breed M.D. (1983) Nestmate recognition in honey bees, Anim. Behav. 31, 86-91. 
Breed M.D., Stiller T.M. (1992) Honey-bee, Apis mellifera, nestmate discrimination - hydrocarbon effects and the evolutionary implications of comb choice, Anim. Behav. 43, 875-883.

Breed M.D., Williams K.R., Fewell J.H. (1988a) Comb wax mediates the acquisition of nest-mate recognition cues in honey bees, Proc. Natl. Acad. Sci. USA 85, 8766-8769.

Breed M.D., Stiller T.M., Moor M.J. (1988b) The ontogeny of kin discrimination cues in the honey bee, Apis mellifera, Behav. Genet. 18, 439-448.

Breed M.D., Garry M.F., Pearce A.N., Hibbard B.E., Bjostad L.B., Page R.E. (1995) The role of wax comb in honey bee nestmate recognition, Anim. Behav. 50, 489-496.

Breed M.D., Leger E.A., Pearce A.N., Wang Y.J. (1998) Comb wax effects on the ontogeny of honey bee nestmate recognition, Anim. Behav. 55, 13-20.

Butler C.G., Free J.B. (1952) The behaviour of worker honeybees at the hive entrance, Behavior 4, 263291.

Butts D.P., Espelie K.E. (1995) Role of nest-paper hydrocarbons in nestmate recognition of Dolichovespula maculata (L.) workers (Hymenoptera, Vespidae), Ethology, 100, 39-49.

Crawley M.J. (1993) GLIM for Ecologists, Blackwell Scientific Publications, Oxford.

de Jong D. (1990) Insects: Hymenoptera (Ants, Wasps, and Bees), in: Morse R.A., Nowogrodzki R. (Eds.) Honey Bee Pests, Predators, and Diseases, 2nd edn. Cornell University Press, Ithaca, New York, pp. 135-155.

Downs S.G., Ratnieks F.L.W. (1999) Recognition of conspecifics by honeybee guards uses nonheritable cues acquired in the adult stage, Anim. Behav. 58, 643-648.

Downs S.G., Ratnieks F.L.W. (2000) Adaptive shifts in honey bee (Apis mellifera L.) guarding behavior support predictions of the acceptance threshold model, Behav. Ecol. 11, 326-333.

Downs S.G., Ratnieks F.L.W., Badcock N.S., Mynott A. (2001) Honeybee guards do not use foodderived odors to recognize non-nest mates: a test of the Odor Convergence Hypothesis, Behav. Ecol. 12, 47-50.

Downs S.G., Ratnieks F.L.W., Jefferies S.L., Rigby H.E. (2000) The role of floral oils in the nestmate recognition system of honey bees (Apis mellifera L.), Apidologie 31, 357-365.

Finney D.J. (1973) Transformation of observations for statistical analysis, Cotton Growing Rev. 50, 1-14.

Francis B.R., Blanton W.E., Littlefield J.L., Nunamaker R.A. (1989) Hydrocarbons of the cuticle and hemolymph of the adult honey bee (Hymenoptera, Apidae), Ann. Entomol. Soc. Am. 82, 486-494.

Free J.B. (1954) The behaviour of robber honeybees, Behavior 7, 233-240.
Frisch K. von (1967) The Dance Language and Orientation of Bees, Harvard University Press, Cambridge, Massachusetts.

Futuyama D.J. (1986) The Evolution of Interactions Among Species, in: Evolutionary Biology, 2nd ed., Sinauer Associates Inc., Sunderland, Massachusetts, pp. 482-504.

Getz W.M., Smith K.B. (1983) Genetic kin recognition - honey bees discriminate between full and half Sisters, Nature 302, 147-148.

Giurfa M., Nunez J., Chittka L., Menzel R. (1995) Color preferences of flower-naïve honeybees, J. Comp. Physiol. A 177, 247-259.

Lunau K., Maier E.J. (1995) Innate color preferences of flower visitors, J. Comp. Physiol. A 177, 1-19.

Maddess T., Davey M.P, Yang E.C. (1999) Discrimination of complex textures by bees, J. Comp. Physiol. A 184, 107-117.

Matsuura M., Sakagami S.F. (1973) A bionomic sketch of the giant hornet, Vespa mandarinia, a serious pest for Japanese agriculture. J. Fac. Sci., Hokkaido Univ. Ser. VI, Zool. 19, 125-162.

Menzel R., Erber J., Masuhr T. (1973) Learning and memory in the honey bee, in: Browne L.B. (Ed.), Experimental Analysis of Insect Behaviour, Springer-Verlag, New York, pp. 195-217.

Moritz R.F.A., Crewe R.M. (1988) Chemical signals of queens in kin recognition of honeybees, Apis mellifera L., J. Comp. Physiol. A 164, 83-89.

Morse R.A. (1966) Honeybee colony defense at low temperatures, J. Econ. Entomol. 59, 1091-1093.

Morse R.A., Shearer D.A., Boch R., Benton A.W. (1967) Observations on alarm substances in the genus Apis, J. Apic. Res. 6, 113-118.

Ono M., Igarashi T., Ohno E., Sasaki M. (1995) Unusual thermal defense by a honeybee against mass attack by hornets, Nature 377, 334-336.

Singer T.L. (1998) Roles of hydrocarbons in the recognition systems of insects, Am. Zool. 38, 394405.

Singer T.L., Espelie K.E. (1992) Social wasps use nest paper hydrocarbons for nestmate recognition, Anim. Behav. 44, 63-68.

Singer T.L., Espelie K.E. (1996) Nest surface hydrocarbons facilitate nestmate recognition for the social wasp, Polistes metricus Say (Hymenoptera: Vespidae), J. Insect Behav. 9, 857-870.

Sledge M.F., Dani F.R., Cervo R., Dapporto L., Turillazzi S. (2001) Recognition of social parasites as nest-mates: adoption of colony-specific host cuticular odours by the paper wasp parasite Polistes sulcifer, Proc. R. Soc. London B 268, 2253-2260.

Spradbery J.P. (1973) Wasps: an account of the biology and natural history of solitary and social wasps, Sidgwick and Jackson, London.

Winston M.L. (1987) The Biology of the Honey Bee, Harvard University Press, Cambridge, Massachusetts. 